\title{
EFFICIENCY ASSESSMENT OF THE USE OF BLOCH-SCHMIGALLA TRIANGULAR METHOD TO IMPROVE THE FUNCTIONING OF COMMERCIAL INDUSTRY ENTERPRISE
}

\author{
Bożena SKOTNICKA-ZASADZIEN' ${ }^{1 *}$, Grzegorz SOWIŃSKI ${ }^{2}$ \\ ${ }^{1}$ Silesian University of Technology, Faculty of Organization and Management, Zabrze; \\ Bozena.Skotnicka@polsl.pl, ORCID: 0000-0003-1717-304X \\ ${ }^{2}$ Silesian University of Technology, Faculty of Organization and Management, Zabrze \\ * Correspondence author
}

Purpose: In order to maintain the highest possible quality of services, more and more often the enterprises make use of proven optimization methods that allow them to maintain competitiveness on the market. One of these methods is spatial placement of workstations that influences the functioning of enterprises. There are many techniques of placing workstations, depending on the business activity run by the company.

Design/methodology/approach: This article presents the use of Bloch-Schmigalla triangular method to improve the placement of office workstations in a commercial industry enterprise. The method used allowed to improve the functioning of the company by shortening the time for forwarding of all documents and information.

Findings: The use of Bloch-Schmigalla triangular method allowed for quick placement of workstations, new placement of workstations. As a result, the workstations will not be as loaded and specific tasks will be performed faster. The time saved can be used to complete other tasks. Thanks to Bloch-Schmigalla triangular method, the distances between the workstations are equal. Before, the distances between several of the workstations were greater than in the case of other ones.

Research limitations/implications: The major limitation of the paper is that it is based on one case of an. In the future, it will be necessary to conduct studies in more organizations so as to find out if the same result can be achieved.

Originality/ value: The article concerned the use of the Bloch-Schmigalli method to improve the positioning of office spaces in a commercial industry company. Until now, this method has not been used to improve the quality of work in office positions.

Keywords: Bloch-Schmigalla triangular method, quality, effectiveness, enterprise.

Category of the paper: Research paper. 


\section{Introduction}

At the beginning of the 1950s, the methods of special of working methods begun to develop. Earlier, till the end of the 1940s, the issues of spatial work organization were discussed within the traditional research on working methods. The development of this area was initiated by W. Bloch, who published a method, according to which objects are placed on a network of equilateral triangles. This method can be used for both production processes, as well as administration and office processes.

The optimization methods, to which the Bloch-Schmigalla triangular method belongs, allow to develop a workstations placement scheme on networks of rectangles (or squares) and triangles, where the normative distances between workstations, the distance between machines and transport routes, as well as building construction elements are taken into account.

Bloch-Schmigalla triangular method is a technique developed by W. Bloch in the 1950s. In 1968, it was modified and developed by H. Schmigalla. The core of this method is a placement of working stations on a network of equilateral triangles. "This methods assumes certain simplifications:

- actual sizes of workstations are being skipped,

- distances between all pairs of neighboring objects are the same and equal to the network module,

- the placed objects must be of the same or similar size" (Stabryła, Trzcieniecki, 1986).

More and more often, this method is being called the Bloch-Schmigalla equilateral triangular method. It is used to optimize the present placement of workstations or to design their location in a completely new place. It is assumed, that the placement of workstations is optimal when the size of goal function, being the product of the flow rate of any factor with a distance of its movement, is minimal (Pasternak, 2005). It can be expressed with the use of the following formula: It can be expressed with the use of the following formula:

$$
\mathrm{Q}=\sum_{i=1}^{n} \sum_{j=1}^{n} \mathrm{~S}_{\mathrm{ij}} * \mathrm{~L}_{(\mathrm{m}) \mathrm{ij}} \rightarrow \min
$$

where:

$\mathrm{Q}$ - summary value of workstations load,

$\mathrm{n}$ - the number of workstations being placed,

$\mathrm{i}, \mathrm{j}$ - placed objects,

$\mathrm{m}_{(\mathrm{i})}$ - placement of $\mathrm{i}$-th object,

$\mathrm{m}_{(\mathrm{i})}$ - placement of $\mathrm{j}$-th object,

$\mathrm{S}_{\mathrm{ij}}$ - ij-th element of load matrix of workstations,

$\mathrm{L}_{\mathrm{m}(\mathrm{ij})}$ - the distance between to workstations where the objects " $\mathrm{i}$ " and " $\mathrm{j}$ " are placed. 
The starting point for the calculation is to determine the number of all $\mathrm{N}$ objects and their links. The obtained matrix is transformed and the $S_{\mathrm{ij}}$ element is selected, that points to a pair of workstations with the strongest linkage. These workstations are placed in the center of the network. If there are several such pairs, the one with the greatest linkage with other objects must be selected. Then, the placement of other objects is decided - in order from the greatest number of linkages with objects that were already placed in the network. If the object being placed is linked with only one object, it is placed in its direct vicinity. If not - a place where the sum of links with the already placed objects is minimal is being chosen.

The correct placement of workstations with the use of Bloch-Schmigalla triangular method has the following benefits for the enterprise:

- Shortening of the production cycle and the decrease of the costs by reducing, for example, unnecessary movements.

- Facilitation of supervision and control over process due to it being harder to misplace materials.

- Easier introduction of changes to the facility functioning.

- Maximization of production volume and services rendered by the enterprise thanks to better use of resources, as well as production and service space.

- Strengthening of the sense of employee unity.

- Maintenance of the proper level of products and services quality (Muhlemann, Oakland, Lockyer, 1995, p. 180).

Placement of workstations is possible almost everywhere, both in production enterprises, as well as in commercial companies, where the employees perform their duties at desks such an enterprise was described in this project.

This article presents the use of Bloch-Schmigalla triangular method to improve the placement of office workstations in a commercial industry enterprise.

\section{Research problem analysis}

In the analyzed enterprise of commercial industry, the employees perform their duties at office workstations. Due to its size and shape, the department where they work (commercial and logistic department in the Silesian voivodeship) resembles a large hall. This gives ample opportunities to organize the new placement of workstations. Currently, the desks are placed in 4 rows, 4 office workstations in each row. This is presented in Figure 1. 


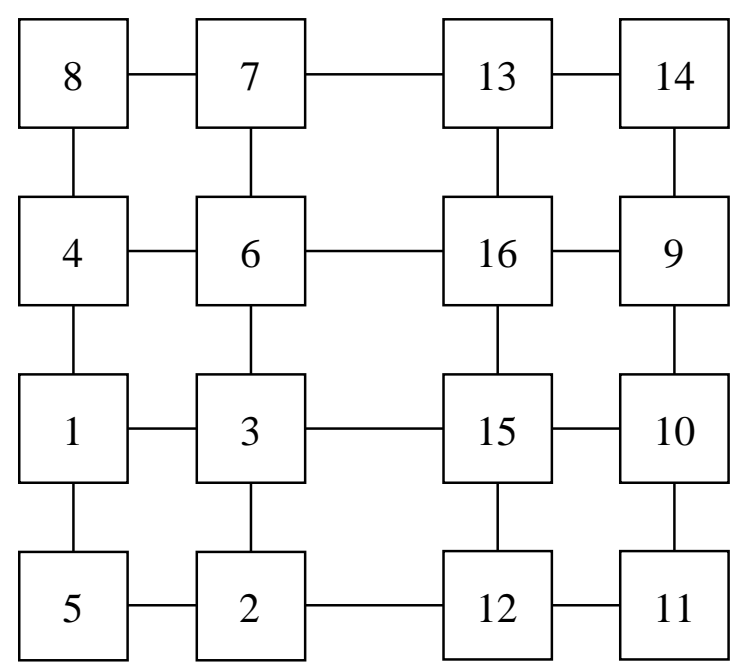

Figure 1. The current arrangement of the workstations in the commercial industry enterprise.

The current arrangement, as presented in Figure 1, may resemble the placement of workstations with the use of CORELAP method. As a result, it is possible to calculate the distance between the workstations - presented in Table 1. It is only a visual resemblance. The last personnel changes resulted in the fact that the new employees were given the free desks - not always taking into account if this will be optimal in terms of the speed of document and information flow. Additionally, the distances between the workstations are not equal. Therefore, research was started to improve the placement of workstations in the studied enterprise.

Table 1.

Distance between workstations in the current arrangement

\begin{tabular}{|c|c|c|c|c|c|c|c|c|c|c|c|c|c|c|c|c|}
\hline \multirow{2}{*}{ Workstation } & \multicolumn{16}{|c|}{ Scope of information flow } \\
\hline & $\mathbf{1}$ & 2 & 3 & 4 & 5 & 6 & 7 & 8 & 9 & \begin{tabular}{|c|}
10 \\
\end{tabular} & 11 & 12 & 13 & 14 & 15 & 16 \\
\hline 1 & $\mathrm{X}$ & 1.41 & 1 & 1 & 1 & 1.41 & 2.24 & 2 & 4.12 & 4 & 4.12 & 3.16 & 3.61 & 4.47 & 3 & 3.16 \\
\hline 2 & & $\mathrm{X}$ & 1 & 2.24 & 1 & 2 & 3 & 3.16 & 3.61 & 3.16 & 3 & 2 & 3.61 & 4.24 & 2.24 & 2.83 \\
\hline 3 & & & $\mathrm{X}$ & 1.41 & 1.41 & 1 & 2 & 2.24 & 3.16 & 3 & 3.16 & 2.24 & 2.83 & 3.61 & 2 & 2.24 \\
\hline 4 & & & & $\mathrm{X}$ & 2 & 1 & 1.41 & 1 & 4 & 4.12 & 4.47 & 3.61 & 3.16 & 4.12 & 3.16 & 3 \\
\hline 5 & & & & & $\mathrm{X}$ & 2.24 & 3.16 & 3 & 4.47 & 4.12 & 4 & 3 & 4.24 & 5 & 3.16 & 3.61 \\
\hline 6 & & & & & & $\mathrm{X}$ & 1 & 1.41 & 3 & 3.16 & 3.61 & 2.83 & 2.24 & 3.16 & 2.24 & 2 \\
\hline 7 & & & & & & & $\mathrm{X}$ & 1 & 3.16 & 3.61 & 4.24 & 3.61 & 2 & 3 & 2.83 & 2.24 \\
\hline 8 & & & & & & & & $X$ & 4.12 & 4.47 & 5 & 4.24 & 3 & 4 & 3.61 & 3.16 \\
\hline 9 & & & & & & & & & $\mathrm{X}$ & 1 & 2 & 2.24 & 1.41 & 1 & 1.41 & 1 \\
\hline 10 & & & & & & & & & & $X$ & 1 & 1.41 & 2.24 & 2 & 1 & 1.41 \\
\hline 11 & & & & & & & & & & & $\mathrm{X}$ & 1 & 3.16 & 3 & 1.41 & 2.24 \\
\hline 12 & & & & & & & & & & & & $X$ & 3 & 3.16 & 1 & 2 \\
\hline 13 & & & & & & & & & & & & & $X$ & 1 & 2 & 1 \\
\hline 14 & & & & & & & & & & & & & & $\mathrm{X}$ & 2.24 & 1.41 \\
\hline 15 & & & & & & & & & & & & & & & $X$ & 1 \\
\hline 16 & & & & & & & & & & & & & & & & $X$ \\
\hline
\end{tabular}

As it can be seen in Table 1, the distances between the workstations are non-measurable. It is an additional difficulty when calculating the goal function. 


\section{Research problem solution}

In the analyzed enterprise, the Bloch-Schmigalla triangular method was used to solve the described problem, as it does not take into account the size of the workstations. In the studied enterprise, all desk are of the same size; additionally, having such a number of workstations, both the calculations, as well as the scheme of arranging subsequent workstations, are easier and the non-measurable values in the goal function are not present.

To begin the workstations placement, first, we need to know the scope of information and documents flow between the employees. For that purpose, for 10 subsequent days, the employees were filling in control check-list presented in Figure 2, and at the end of the day they entered the number of information flow and the number of workstations. In the research, the following persons were not included: President of the Management Board, warehouse workers and drivers, due to the performed functions.

KARTA KONTROLNA PRACOWNIKA

(Wpisać swój kod)

Proszę o uzupełnienie poniższej karty.

Przez najbliższych 10 dni roboczych proszę wpisywać, ile przekazał Pan/Pani dokumentów innym pracownikom każdego dnia.

\begin{tabular}{|l|l|l|l|l|l|l|l|l|l|l|l|}
\hline & \multicolumn{10}{|c|}{ Dzień roboczy } \\
\hline Kod pracownika & 1 & 2 & 3 & 4 & 5 & 6 & 7 & 8 & 9 & 10 & Razem \\
\hline & & & & & & & & & & & \\
\hline & & & & & & & & & & & \\
\hline & & & & & & & & & & & \\
\hline & & & & & & & & & & & \\
\hline & & & & & & & & & & & \\
\hline & & & & & & & & & & & \\
\hline & & & & & & & & & & & \\
\hline & & & & & & & & & & & \\
\hline & & & & & & & & & & & \\
\hline & & & & & & & & & & & \\
\hline & & & & & & & & & & & \\
\hline & & & & & & & & & & & \\
\hline & & & & & & & & & & & \\
\hline & & & & & & & & & & & \\
\hline & & & & & & & & & & & \\
\hline
\end{tabular}

Dziękuję za wypełnienie i poświęcenie czasu.

Numer stanowiska: .............

Figure 2. Employee's control check-list that the personnel was asked to fill in. 
Once all control check-lists were collected and the values were calculated, the scope of documents flow was presented in Table 2.

Table 2.

Scope of information flow in the commercial industry enterprise

\begin{tabular}{|c|c|c|c|c|c|c|c|c|c|c|c|c|c|c|c|c|}
\hline \multirow{2}{*}{ Workstation } & \multicolumn{16}{|c|}{ Scope of information flow } \\
\hline & 1 & 2 & 3 & 4 & 5 & 6 & 7 & $\mathbf{8}$ & 9 & $\mathbf{1 0}$ & 11 & 12 & 13 & 14 & 15 & 16 \\
\hline 1 & $\mathrm{X}$ & 55 & 72 & 107 & 36 & 0 & 0 & 0 & 0 & 0 & 0 & 0 & 0 & 0 & 159 & 104 \\
\hline 2 & 33 & $\mathrm{X}$ & 61 & 85 & 48 & 0 & 0 & 0 & 0 & 0 & 0 & 0 & 0 & 0 & 82 & 93 \\
\hline 3 & 56 & 23 & $X$ & 73 & 54 & 0 & 0 & 0 & 0 & 0 & 0 & 0 & 0 & 0 & 71 & 47 \\
\hline 4 & 135 & 93 & 96 & $\mathrm{X}$ & 27 & 0 & 0 & 0 & 0 & 0 & 0 & 0 & 0 & 0 & 63 & 66 \\
\hline 5 & 44 & 60 & 38 & 15 & $\mathrm{X}$ & 0 & 0 & 0 & 0 & 0 & 0 & 0 & 0 & 0 & 45 & 57 \\
\hline 6 & 0 & 0 & 0 & 0 & 0 & $\mathrm{X}$ & 65 & 82 & 0 & 0 & 0 & 0 & 0 & 0 & 81 & 125 \\
\hline 7 & 0 & 0 & 0 & 0 & 0 & 53 & $X$ & 76 & 0 & 0 & 0 & 0 & 0 & 0 & 102 & 88 \\
\hline 8 & 0 & 0 & 0 & 0 & 0 & 111 & 92 & $X$ & 0 & 0 & 0 & 0 & 0 & 0 & 55 & 79 \\
\hline 9 & 0 & 0 & 0 & 0 & 0 & 0 & 0 & 0 & $\mathrm{X}$ & 97 & 61 & 117 & 82 & 108 & 105 & 88 \\
\hline 10 & 0 & 0 & 0 & 0 & 0 & 0 & 0 & 0 & 69 & $X$ & 89 & 41 & 128 & 54 & 72 & 129 \\
\hline 11 & 0 & 0 & 0 & 0 & 0 & 0 & 0 & 0 & 47 & 68 & $X$ & 33 & 18 & 79 & 63 & 68 \\
\hline 12 & 0 & 0 & 0 & 0 & 0 & 0 & 0 & 0 & 80 & 62 & 38 & $X$ & 57 & 22 & 51 & 105 \\
\hline 13 & 0 & 0 & 0 & 0 & 0 & 0 & 0 & 0 & \begin{tabular}{|l|}
52 \\
\end{tabular} & 103 & 54 & 37 & $X$ & 46 & 42 & 74 \\
\hline 14 & 0 & 0 & 0 & 0 & 0 & 0 & 0 & 0 & 88 & 67 & 52 & 43 & 28 & $X$ & 36 & 58 \\
\hline 15 & 102 & 94 & 68 & 83 & 39 & 81 & 106 & 56 & 135 & 101 & 47 & 62 & 29 & 54 & $\mathrm{X}$ & 77 \\
\hline 16 & 127 & 87 & 62 & 65 & 38 & 104 & \begin{tabular}{|l|}
121 \\
\end{tabular} & 89 & 73 & 84 & 51 & 129 & 73 & 35 & 71 & $X$ \\
\hline
\end{tabular}

Next, the values for subsequent links must be summed up.

Table 3.

Scope of information flow after summing up the values for mutual links in the commercial industry enterprise

\begin{tabular}{|c|c|c|c|c|c|c|c|c|c|c|c|c|c|c|c|c|}
\hline \multirow{2}{*}{ Workstation } & \multicolumn{10}{|c|}{ Scope of information flow } \\
\cline { 2 - 15 } & $\mathbf{1}$ & $\mathbf{2}$ & $\mathbf{3}$ & $\mathbf{4}$ & $\mathbf{5}$ & $\mathbf{6}$ & $\mathbf{7}$ & $\mathbf{8}$ & $\mathbf{9}$ & $\mathbf{1 0}$ & $\mathbf{1 1}$ & $\mathbf{1 2}$ & $\mathbf{1 3}$ & $\mathbf{1 4}$ & $\mathbf{1 5}$ & $\mathbf{1 6}$ \\
\hline $\mathbf{1}$ & $\mathrm{X}$ & 88 & 128 & 242 & 80 & 0 & 0 & 0 & 0 & 0 & 0 & 0 & 0 & 0 & $\mathbf{2 6 1}$ & 231 \\
\hline $\mathbf{2}$ & & $\mathrm{X}$ & 84 & 178 & 108 & 0 & 0 & 0 & 0 & 0 & 0 & 0 & 0 & 0 & 176 & 180 \\
\hline $\mathbf{3}$ & & & $\mathrm{X}$ & 169 & 92 & 0 & 0 & 0 & 0 & 0 & 0 & 0 & 0 & 0 & 139 & 109 \\
\hline $\mathbf{4}$ & & & & $\mathrm{X}$ & 42 & 0 & 0 & 0 & 0 & 0 & 0 & 0 & 0 & 0 & 146 & 131 \\
\hline $\mathbf{5}$ & & & & & $\mathrm{X}$ & 0 & 0 & 0 & 0 & 0 & 0 & 0 & 0 & 0 & 84 & 95 \\
\hline $\mathbf{6}$ & & & & & & $\mathrm{X}$ & 118 & 193 & 0 & 0 & 0 & 0 & 0 & 0 & 162 & 229 \\
\hline $\mathbf{7}$ & & & & & & & $\mathrm{X}$ & 168 & 0 & 0 & 0 & 0 & 0 & 0 & 208 & 209 \\
\hline $\mathbf{8}$ & & & & & & & & $\mathrm{X}$ & 0 & 0 & 0 & 0 & 0 & 0 & 111 & 168 \\
\hline $\mathbf{9}$ & & & & & & & & & $\mathrm{X}$ & 166 & 108 & 197 & 134 & 196 & 240 & 161 \\
\hline $\mathbf{1 0}$ & & & & & & & & & & $\mathrm{X}$ & 157 & 103 & 231 & 121 & 173 & 213 \\
\hline $\mathbf{1 1}$ & & & & & & & & & & & $\mathrm{X}$ & 71 & 72 & 131 & 110 & 119 \\
\hline $\mathbf{1 2}$ & & & & & & & & & & & & $\mathrm{X}$ & 94 & 65 & 113 & 234 \\
\hline $\mathbf{1 3}$ & & & & & & & & & & & & & $\mathrm{X}$ & 74 & 71 & 147 \\
\hline $\mathbf{1 4}$ & & & & & & & & & & & & & & $\mathrm{X}$ & 90 & 93 \\
\hline $\mathbf{1 5}$ & & & & & & & & & & & & & & & $\mathrm{X}$ & 148 \\
\hline $\mathbf{1 6}$ & & & & & & & & & & & & & & & & $\mathrm{X}$ \\
\hline
\end{tabular}

Knowing the distances between the workstations and the scope of document flows between then, on the basis of Table 1 and 3, the goal function could be calculated by summing the products of distances and flows between all workstations: 
$\mathbf{Q}=1.41 * 88+128+242+80+3 * 261+3.16 * 231+84+2.24 * 178+108+2.24 * 176+$ $2.83 * 180+1.41 * 169+1.41 * 92+2 * 139+2.24 * 109+2 * 42+3.16 * 146+3 * 131+3.16 * 84+$ $3 * 95+118+1.41 * 193+2.24 * 162+2 * 229+168+2.83 * 208+2.24 * 209+3.61 * 111+$ $3.16 * 168+166+2 * 108+2.24 * 197+1.41 * 134+196+1.41 * 240+161+157+1.41 * 103+$ $2.24 * 231+2 * 121+173+1.41 * 213+71+3.16 * 72+3 * 131+1.41 * 110+2.24 * 119+3 * 94$ $+3.16 * 65+113+2 * 234+74+2 * 71+147+2.24 * 90+1.41 * 93+148=\mathbf{1 5 5 9 5 . 7}$.

As it can be seen in Table 3, the strongest linkage is between the workstations no. 1 and 15 . Now a table (Table 4) can be drawn up, that allows to determine in what order the subsequent workstations are to be placed - similarly as in Tables 2 and 3.

Table 4.

Values of linkages between the workstations

\begin{tabular}{|c|c|c|c|c|c|c|c|c|c|c|c|c|c|c|}
\hline Workstation & 2 & 3 & 4 & 5 & 6 & 7 & 8 & 9 & 10 & 11 & 12 & 13 & 14 & 16 \\
\hline 1 & 88 & 128 & 242 & 80 & 0 & 0 & 0 & 0 & 0 & 0 & 0 & 0 & 0 & 231 \\
\hline 15 & 176 & 139 & 146 & 84 & 162 & 208 & 111 & 240 & 173 & 110 & 113 & 71 & 90 & 148 \\
\hline$\sum$ & 264 & 267 & 388 & 164 & 162 & 208 & 111 & 240 & 173 & 110 & 113 & 71 & 90 & 379 \\
\hline 4 & 178 & 169 & --- & 42 & 0 & 0 & 0 & 0 & 0 & 0 & 0 & 0 & 0 & 131 \\
\hline$\sum$ & 442 & 436 & --- & 206 & 162 & 208 & 111 & 240 & 173 & 110 & 113 & 71 & 90 & 510 \\
\hline 16 & 180 & 109 & --- & 95 & 229 & 209 & 168 & 161 & 213 & 119 & 234 & 147 & 93 & --- \\
\hline$\sum$ & 622 & 545 & --- & 301 & 391 & 417 & 279 & 401 & 386 & 229 & 347 & 218 & 183 & --- \\
\hline 2 & --- & 84 & --- & 108 & 0 & 0 & 0 & 0 & 0 & 0 & 0 & 0 & 0 & --- \\
\hline$\sum$ & --- & 629 & --- & 409 & 391 & 417 & 279 & 401 & 386 & 229 & 347 & 218 & 183 & --- \\
\hline 3 & --- & --- & --- & 92 & 0 & 0 & 0 & 0 & 0 & 0 & 0 & 0 & 0 & --- \\
\hline$\sum$ & --- & --- & --- & 501 & 391 & 417 & 279 & 401 & 386 & 229 & 347 & 218 & 183 & --- \\
\hline 5 & --- & --- & --- & --- & 0 & 0 & 0 & 0 & 0 & 0 & 0 & 0 & 0 & --- \\
\hline$\sum$ & --- & --- & --- & --- & 391 & 417 & 279 & 401 & 386 & 229 & 347 & 218 & 183 & --- \\
\hline 7 & --- & --- & --- & --- & 118 & --- & 168 & 0 & 0 & 0 & 0 & 0 & 0 & --- \\
\hline$\sum$ & --- & --- & --- & --- & 509 & --- & 447 & 401 & 386 & 229 & 347 & 218 & 183 & --- \\
\hline 6 & --- & --- & --- & --- & ---- & --- & 193 & 0 & 0 & 0 & 0 & 0 & 0 & --- \\
\hline$\sum$ & --- & --- & --- & --- & --- & --- & 640 & 401 & 386 & 229 & 347 & 218 & 183 & --- \\
\hline 8 & --- & --- & --- & --- & ---- & --- & --- & 0 & 0 & 0 & 0 & 0 & 0 & --- \\
\hline$\sum$ & --- & --- & --- & --- & --- & --- & --- & 401 & 386 & 229 & 347 & 218 & 183 & --- \\
\hline 9 & --- & --- & --- & --- & --- & --- & --- & --- & 166 & 108 & 197 & 134 & 196 & --- \\
\hline$\sum$ & --- & --- & --- & --- & --- & --- & --- & --- & 552 & 337 & 544 & 352 & 379 & --- \\
\hline 10 & -- & --- & --- & --- & --- & --- & --- & --- & $\begin{array}{l}--- \\
\end{array}$ & 157 & 103 & 231 & 121 & --- \\
\hline$\sum$ & -- & --- & --- & --- & --- & --- & -- & --- & --- & 494 & 647 & 583 & 500 & -- \\
\hline 12 & --- & --- & ---- & ---- & ---- & --- & --- & --- & ---- & 71 & --- & 94 & 65 & --- \\
\hline$\sum$ & - & --- & --- & --- & --- & --- & --- & --- & --- & 565 & --- & 677 & 565 & --- \\
\hline 13 & --- & -- & --- & --- & --- & --- & -- & --- & --- & 72 & --- & ---- & 74 & -- \\
\hline$\sum$ & --- & --- & --- & --- & --- & --- & --- & --- & --- & 637 & --- & --- & 639 & - \\
\hline 14 & --- & - -- & -- & --- & --- & --- & - --- & --- & --- & 79 & --- & $\begin{array}{l}--- \\
-1\end{array}$ & --- & --- \\
\hline$\sum$ & --- & --- & --- & $\begin{array}{l}--- \\
\end{array}$ & --- & ---- & --- & ---- & ---- & 716 & --- & --- & ---- & --- \\
\hline
\end{tabular}

In accordance with table 4, the workstations should be placed as follows: 1, 15, 4, 16, 2, 3, $5,7,6,8,9,10,12,13,14,11$. 


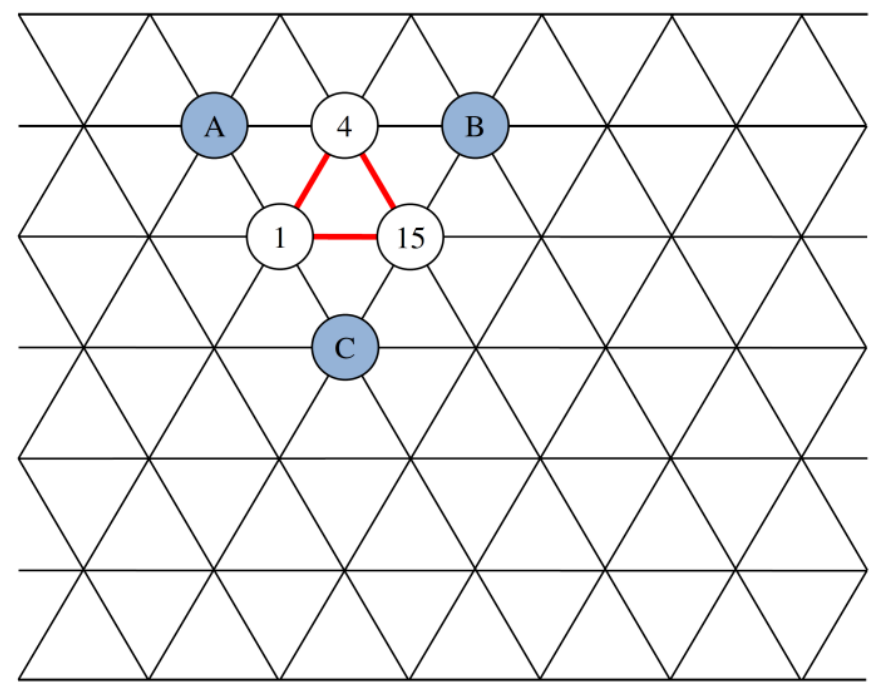

Figure 3. Placement of workstations no. 1, 15 and 4 on the equilateral triangles network and possible placement of workstation 16.

After placing the first three workstations no. 1, 15 and 4, the goal function value in accordance with formula (1) equals: $\mathbf{Q}=\mathbf{2 6 1}+\mathbf{3 8 8}=\mathbf{6 4 9}$.

Table 5.

Scope of flows of workstation no. 16, as compared with other workstations

\begin{tabular}{|c|c|c|c|}
\hline & \multicolumn{3}{|c|}{ Amount of work } \\
\hline Workstation & A & B & C \\
\hline Node & 231 & 462 & 148 \\
1 & 296 & 148 & 262 \\
15 & 131 & 131 & $\mathbf{6 4 1}$ \\
4 & 658 & 741 & \\
\hline
\end{tabular}

In line with Table 5, the next workstation, that is no. 16, will be placed in point $\mathrm{C}$.

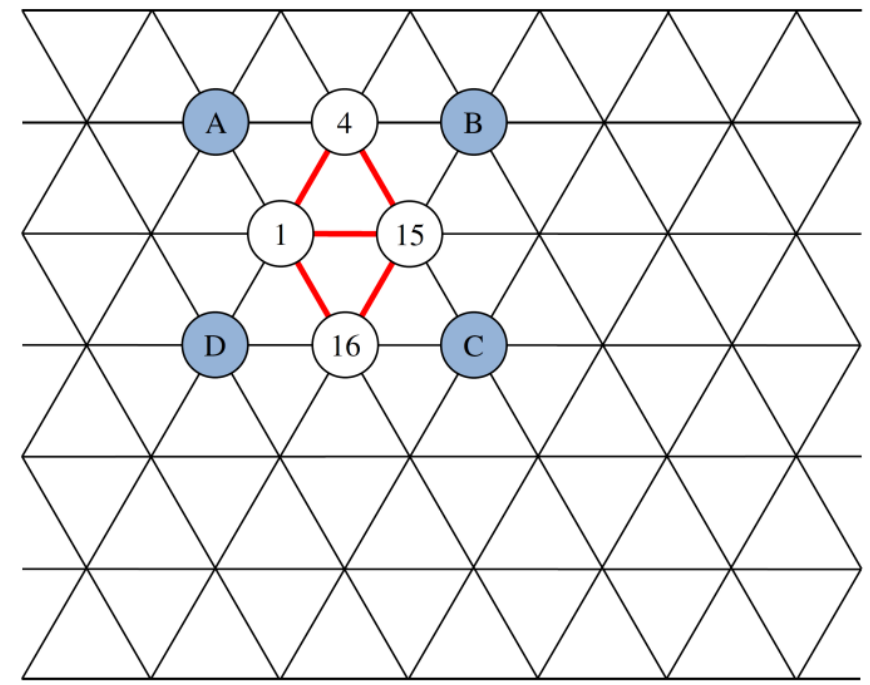

Figure 4. Placement of workstation no. 16 on the equilateral triangles network and possible placement of workstation no. 2. 
Once the workstation no. 16 has been placed in the vicinity of workstations no. 1 and 15 , the goal function equals: $Q=649+641=1290$.

Table 6.

Scope of flows of workstation no. 2, as compared with other workstations

\begin{tabular}{|c|c|c|c|c|}
\hline & \multicolumn{4}{|c|}{ Amount of work } \\
\hline Workstation & A & B & C & D \\
\hline Node & & & & \\
1 & 88 & 176 & 176 & 88 \\
15 & 352 & 176 & 176 & 352 \\
4 & 178 & 178 & 356 & 356 \\
16 & 360 & 360 & 180 & 180 \\
\hline Total & 978 & 890 & $\mathbf{8 8 8}$ & 976 \\
\hline
\end{tabular}

In line with Table 6 , the next workstation, that is no. 2 , will be placed in point $\mathrm{C}$.

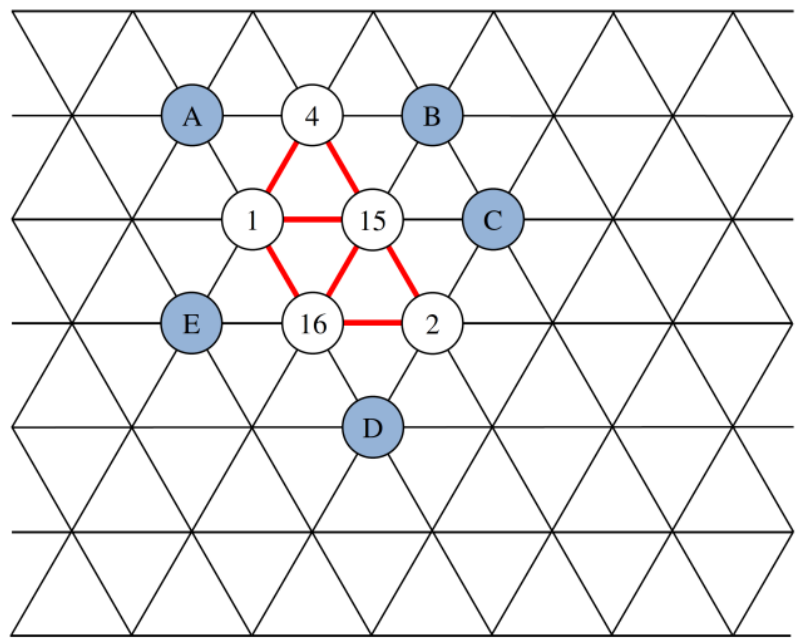

Figure 5. Placement of workstation no. 2 on the equilateral triangles network and possible placement of workstation no. 3 .

Once the workstation no. 2 has been placed in the vicinity of workstations no. 15 and 16 , the goal function equals: $\mathbf{Q}=\mathbf{1 2 9 0}+\mathbf{8 8 8}=\mathbf{2 1 7 8}$.

Table 7.

Scope of flows of workstation no. 3, as compared with other workstations

\begin{tabular}{|c|c|c|c|c|c|}
\hline & \multicolumn{5}{|c|}{ Amount of work } \\
\hline Workstation & A & B & C & D & E \\
\hline Node & & & & & \\
1 & 128 & 256 & 256 & 256 & 256 \\
15 & 278 & 139 & 139 & 278 & 278 \\
4 & 169 & 169 & 338 & 507 & 507 \\
16 & 218 & 218 & 218 & 109 & 109 \\
2 & 252 & 168 & 84 & 84 & 168 \\
\hline Total & 1045 & $\mathbf{9 5 0}$ & 1035 & 1234 & 1318 \\
\hline
\end{tabular}

In line with Table 7, the next workstation, that is no. 3 , will be placed in point $\mathrm{B}$. 


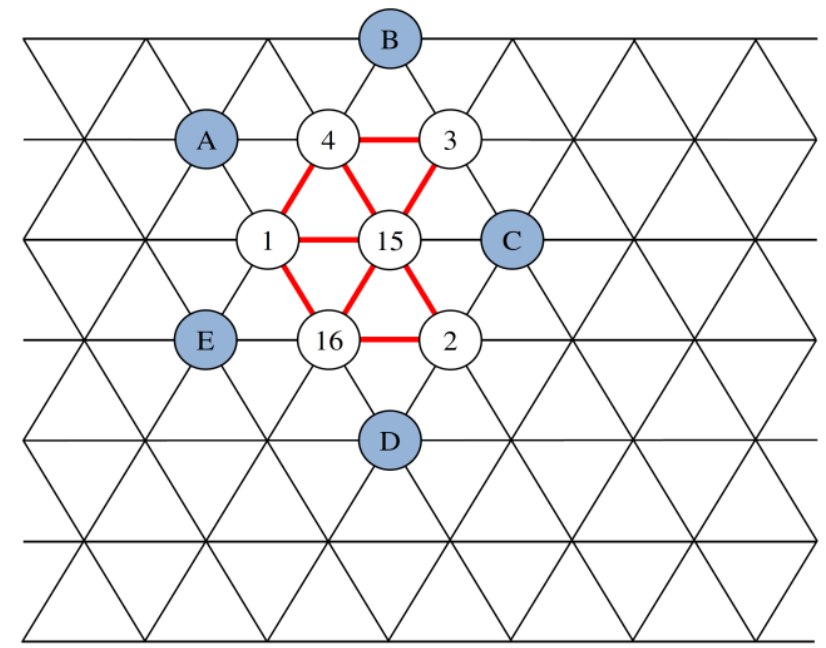

Figure 6. Placement of workstation no. 3 on the equilateral triangles network and possible placement of workstation no. 5 .

Once the workstation no. 3 has been placed in the vicinity of workstations no. 4 and 15 , the goal function equals: $\mathbf{Q}=\mathbf{2 1 7 8}+\mathbf{9 5 0}=\mathbf{3 1 2 8}$.

Table 8.

Scope of flows of workstation no. 5, as compared with other workstations

\begin{tabular}{|c|c|c|c|c|c|}
\hline & \multicolumn{5}{|c|}{ Amount of work } \\
\hline Workstation & A & B & C & D & E \\
\hline Node & & & & & \\
1 & 80 & 160 & 160 & 160 & 80 \\
15 & 168 & 168 & 84 & 168 & 168 \\
4 & 42 & 42 & 84 & 126 & 84 \\
16 & 190 & 285 & 190 & 95 & 95 \\
2 & 324 & 324 & 108 & 108 & 216 \\
3 & 184 & 92 & 92 & 276 & 276 \\
\hline Total & 988 & 1071 & $\mathbf{7 1 8}$ & 933 & 919 \\
\hline
\end{tabular}

In line with Table 8, the next workstation, that is no. 5, will be placed in point $\mathrm{C}$.

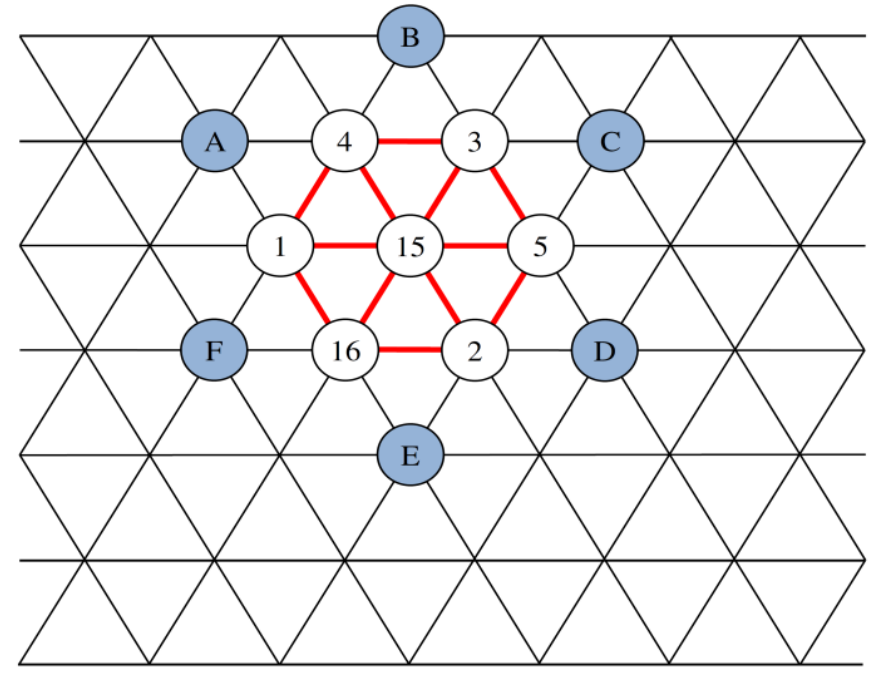

Figure 7. Placement of workstation no. 5 on the equilateral triangles network and possible placement of workstation no. 7. 
Once the workstation no. 5 has been placed in the vicinity of workstations no. 2.3 and 15, the goal function equals: $\mathbf{Q}=\mathbf{3 1 2 8}+\mathbf{7 1 8}=\mathbf{3 8 4 6}$.

Table 9.

Scope of flows of workstation no. 7, as compared with other workstations

\begin{tabular}{|c|c|c|c|c|c|c|}
\hline & \multicolumn{7}{|c|}{ Amount of work } \\
\hline Workstation & A & B & C & D & E & F \\
\hline Node & & & & & & \\
1 & 0 & 0 & 0 & 0 & 0 & 0 \\
15 & 416 & 416 & 416 & 416 & 416 & 416 \\
4 & 0 & 0 & 0 & 0 & 0 & 0 \\
16 & 418 & 627 & 627 & 418 & 209 & 209 \\
2 & 0 & 0 & 0 & 0 & 0 & 0 \\
3 & 0 & 0 & 0 & 0 & 0 & 0 \\
5 & 0 & 0 & 0 & 0 & 0 & 0 \\
\hline Total & 834 & 1043 & 1043 & 834 & $\mathbf{6 2 5}$ & $\mathbf{6 2 5}$ \\
\hline
\end{tabular}

In line with table 9, the subsequent workstation no. 7 can be placed in point $\mathrm{E}$ or $\mathrm{F}$. In line with the rule described in an example in chapter 1.2.1, it can be any point. Therefore, point $\mathrm{F}$ is being chosen.

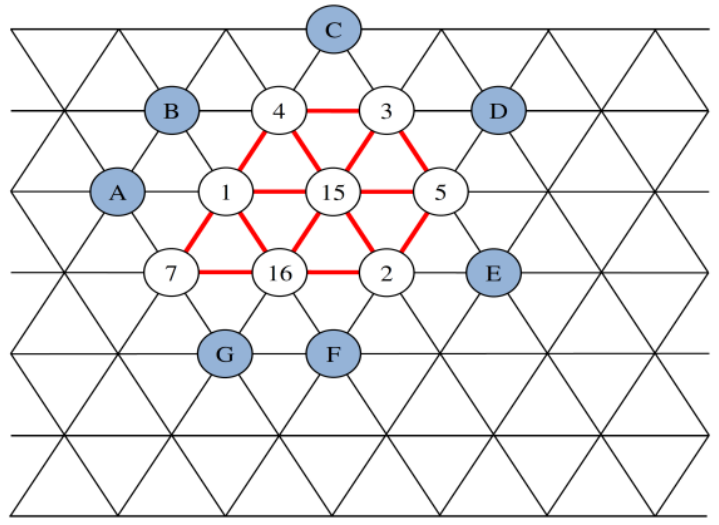

Figure 8. Placement of workstation no. 7 on the equilateral triangles network and possible placement of workstation no. 6 .

Once the workstation no. 7 has been placed in the vicinity of workstations no. 1 and 16 , the goal function equals: $Q=3846+625=4471$.

Table 10.

Scope of flows of workstation no. 6, as compared with other workstations

\begin{tabular}{|c|c|c|c|c|c|c|c|}
\hline & \multicolumn{7}{|c|}{ Amount of work } \\
\hline Workstation & A & B & C & D & E & F & G \\
\hline Node & & & & & & & \\
1 & 0 & 0 & 0 & 0 & 0 & 0 & 0 \\
15 & 324 & 324 & 324 & 324 & 324 & 324 & 324 \\
4 & 0 & 0 & 0 & 0 & 0 & 0 & 0 \\
16 & 458 & 458 & 687 & 687 & 458 & 229 & 229 \\
2 & 0 & 0 & 0 & 0 & 0 & 0 & 0 \\
3 & 0 & 0 & 0 & 0 & 0 & 0 & 0 \\
5 & 0 & 0 & 0 & 0 & 0 & 0 & 0 \\
7 & 118 & 236 & 354 & 472 & 354 & 236 & 118 \\
\hline Total & 900 & 1018 & 1365 & 1483 & 1136 & 789 & $\mathbf{6 7 1}$ \\
\hline
\end{tabular}


In line with Table 10, the next workstation, that is no. 6 , will be placed in point $\mathrm{G}$.

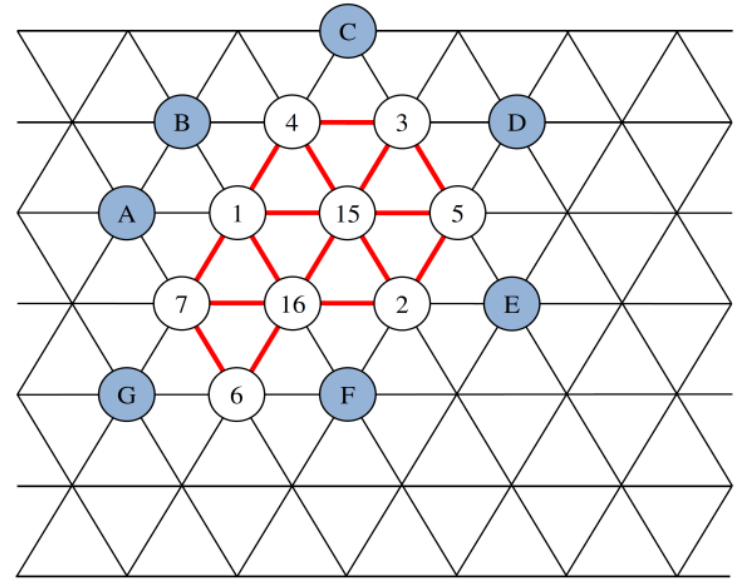

Figure 9. Placement of workstation no. 6 on the equilateral triangles network and possible placement of workstation no. 8 .

Once the workstation no. 6 has been placed in the vicinity of workstations no. 7 and 16, the goal function equals: $Q=\mathbf{4 4 7 1}+\mathbf{6 7 1}=\mathbf{5 1 4 2}$.

Table 10.

Scope of flows of workstation no. 8, as compared with other workstations

\begin{tabular}{|c|c|c|c|c|c|c|c|}
\hline & \multicolumn{7}{|c|}{ Amount of work } \\
\hline Workstation & A & B & C & D & E & F & G \\
\hline Node & & & & & & & \\
1 & 0 & 0 & 0 & 0 & 0 & 0 & 0 \\
15 & 222 & 222 & 222 & 222 & 222 & 222 & 333 \\
4 & 0 & 0 & 0 & 0 & 0 & 0 & 0 \\
16 & 336 & 336 & 504 & 504 & 336 & 168 & 336 \\
2 & 0 & 0 & 0 & 0 & 0 & 0 & 0 \\
3 & 0 & 0 & 0 & 0 & 0 & 0 & 0 \\
5 & 0 & 0 & 0 & 0 & 0 & 0 & 0 \\
7 & 168 & 336 & 504 & 672 & 504 & 336 & 168 \\
6 & 386 & 579 & 772 & 772 & 579 & 193 & 193 \\
\hline Total & 1112 & 1473 & 2002 & 2170 & 1641 & $\mathbf{9 1 9}$ & 1030 \\
\hline
\end{tabular}

In line with Table 10, the next workstation, that is no. 6 , will be placed in point $\mathrm{G}$.

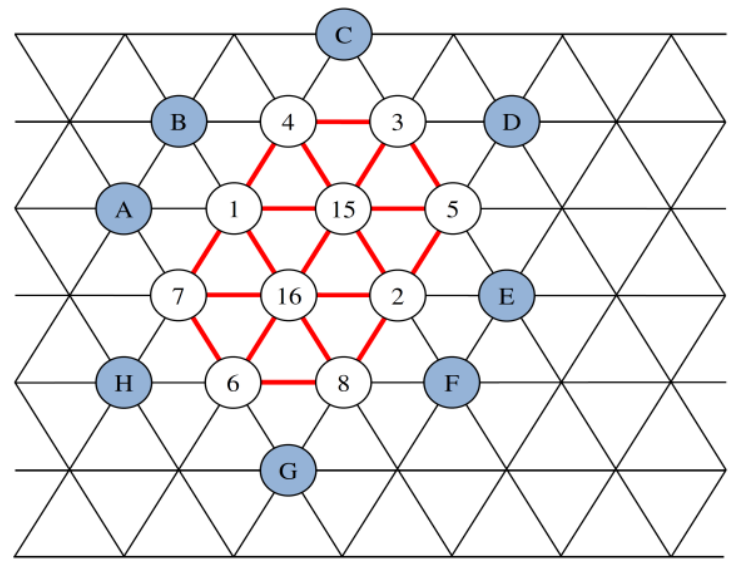

Figure 10. Placement of workstation no. 8 on the equilateral triangles network and possible placement of workstation no. 9. 
Once the workstation no. 8 has been placed in the vicinity of workstations no. 2, 6 and 16, the goal function equals: $Q=5142+919=6061$.

Table 11.

Scope of flows of workstation no. 9, as compared with other workstations

\begin{tabular}{|c|c|c|c|c|c|c|c|c|}
\hline & \multicolumn{9}{|c|}{ Amount of work } \\
\hline Workstation & A & B & C & D & E & F & G & H \\
\hline Node & & & & & & & & \\
1 & 0 & 0 & 0 & 0 & 0 & 0 & 0 & 0 \\
15 & 480 & 480 & 480 & 480 & 480 & 480 & 720 & 720 \\
4 & 0 & 0 & 0 & 0 & 0 & 0 & 0 & 0 \\
16 & 322 & 322 & 483 & 483 & 322 & 322 & 322 & 322 \\
2 & 0 & 0 & 0 & 0 & 0 & 0 & 0 & 0 \\
3 & 0 & 0 & 0 & 0 & 0 & 0 & 0 & 0 \\
5 & 0 & 0 & 0 & 0 & 0 & 0 & 0 & 0 \\
7 & 0 & 0 & 0 & 0 & 0 & 0 & 0 & 0 \\
6 & 0 & 0 & 0 & 0 & 0 & 0 & 0 & 0 \\
8 & 0 & 0 & 0 & 0 & 0 & 0 & 0 & 0 \\
\hline Total & $\mathbf{8 0 2}$ & $\mathbf{8 0 2}$ & 963 & 963 & $\mathbf{8 0 2}$ & $\mathbf{8 0 2}$ & 1042 & 1042 \\
\hline
\end{tabular}

In line with Table 11, the next workstation, that is no. 9, can be placed in points $\mathrm{A}, \mathrm{B}, \mathrm{E}, \mathrm{F}$. Point $\mathrm{F}$ is being chosen.

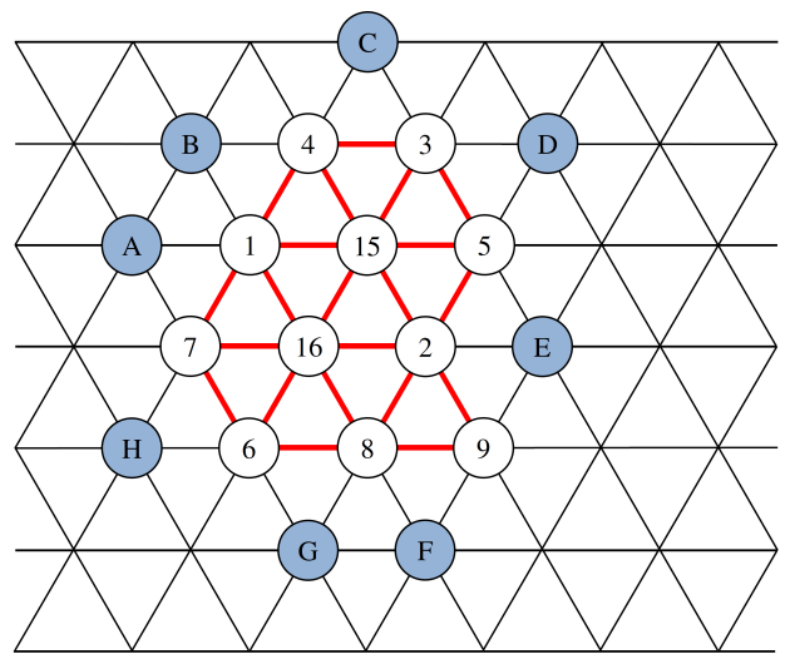

Figure 11. Placement of workstation no. 9 on the equilateral triangles network and possible placement of workstation no. 10.

Once the workstation no. 9 was placed in the vicinity of workstations no. 2 and 8 , the goal function equals: $Q=6061+802=6863$.

Table 12.

Scope of flows of workstation no. 10, as compared with other workstations

\begin{tabular}{|c|c|c|c|c|c|c|c|c|}
\hline & \multicolumn{9}{|c|}{ Amount of work } \\
\hline Workstation & A & B & C & D & E & F & G & H \\
\hline Node & & & & & & & & \\
1 & 0 & 0 & 0 & 0 & 0 & 0 & 0 & 0 \\
15 & 346 & 346 & 346 & 346 & 346 & 519 & 519 & 519 \\
4 & 0 & 0 & 0 & 0 & 0 & 0 & 0 & 0 \\
16 & 426 & 426 & 639 & 639 & 426 & 426 & 426 & 426
\end{tabular}


Cont. table 12.

\begin{tabular}{|c|c|c|c|c|c|c|c|c|}
2 & 0 & 0 & 0 & 0 & 0 & 0 & 0 & 0 \\
3 & 0 & 0 & 0 & 0 & 0 & 0 & 0 & 0 \\
5 & 0 & 0 & 0 & 0 & 0 & 0 & 0 & 0 \\
7 & 0 & 0 & 0 & 0 & 0 & 0 & 0 & 0 \\
6 & 0 & 0 & 0 & 0 & 0 & 0 & 0 & 0 \\
8 & 0 & 0 & 0 & 0 & 0 & 0 & 0 & 0 \\
9 & 664 & 664 & 664 & 498 & 166 & 166 & 332 & 498 \\
\hline Total & 1436 & 1436 & 1649 & 1483 & $\mathbf{9 3 8}$ & 1111 & 1277 & 1443 \\
\hline
\end{tabular}

In line with Table 12, the next workstation, that is no. 10, will be placed in point $\mathrm{E}$.

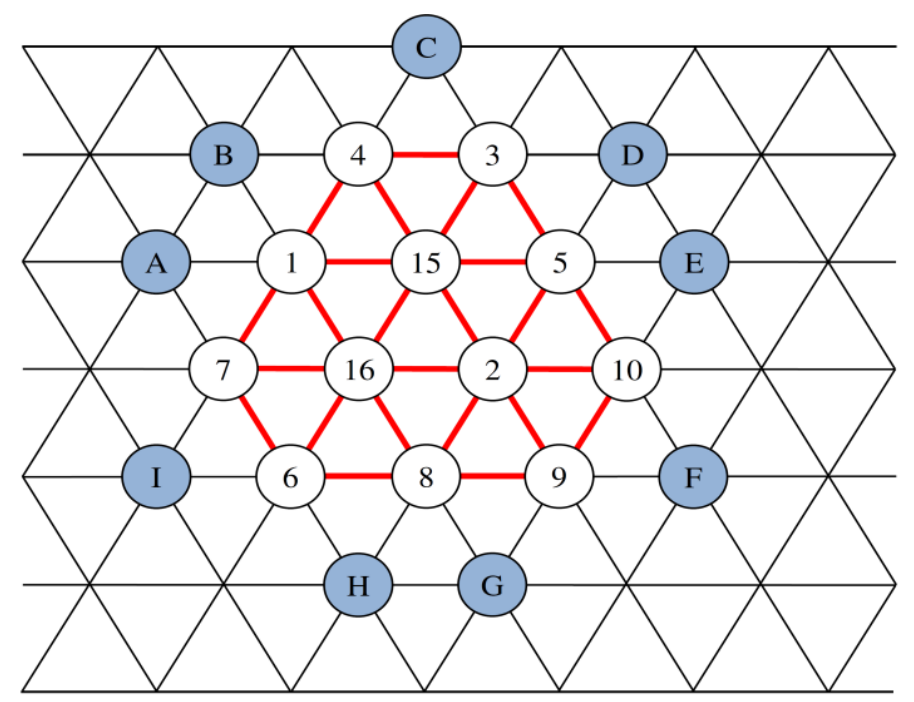

Figure 12. Placement of workstation no. 10 on the equilateral triangles network and possible placement of workstation no. 12.

Once the workstation no. 10 has been placed in the vicinity of workstations no. 2, 5 and 9 , the goal function equals: $\mathbf{Q}=\mathbf{6 8 6 3}+\mathbf{9 3 8}=\mathbf{7 8 0 1}$.

Table 13.

Scope of flows of workstation no. 12, as compared with other workstations

\begin{tabular}{|c|c|c|c|c|c|c|c|c|c|}
\hline & \multicolumn{9}{|c|}{ Amount of work } \\
\hline Workstation & A & B & C & D & E & F & G & H & I \\
\hline Node & & & & & & & & & \\
1 & 0 & 0 & 0 & 0 & 0 & 0 & 0 & 0 & 0 \\
15 & 226 & 226 & 226 & 226 & 226 & 339 & 339 & 339 & 339 \\
4 & 0 & 0 & 0 & 0 & 0 & 0 & 0 & 0 & 0 \\
16 & 468 & 468 & 702 & 702 & 702 & 702 & 468 & 468 & 468 \\
2 & 0 & 0 & 0 & 0 & 0 & 0 & 0 & 0 & 0 \\
3 & 0 & 0 & 0 & 0 & 0 & 0 & 0 & 0 & 0 \\
5 & 0 & 0 & 0 & 0 & 0 & 0 & 0 & 0 & 0 \\
7 & 0 & 0 & 0 & 0 & 0 & 0 & 0 & 0 & 0 \\
6 & 0 & 0 & 0 & 0 & 0 & 0 & 0 & 0 & 0 \\
8 & 0 & 0 & 0 & 0 & 0 & 0 & 0 & 0 & 0 \\
9 & 788 & 788 & 788 & 591 & 394 & 197 & 197 & 394 & 591 \\
10 & 412 & 412 & 309 & 206 & 103 & 103 & 206 & 309 & 412 \\
\hline Total & 1894 & 1894 & 2025 & 1725 & 1425 & 1341 & $\mathbf{1 2 1 0}$ & 1510 & 1810 \\
\hline
\end{tabular}

In line with Table 13, the next workstation, that is no. 12, will be placed in point $\mathrm{G}$. 


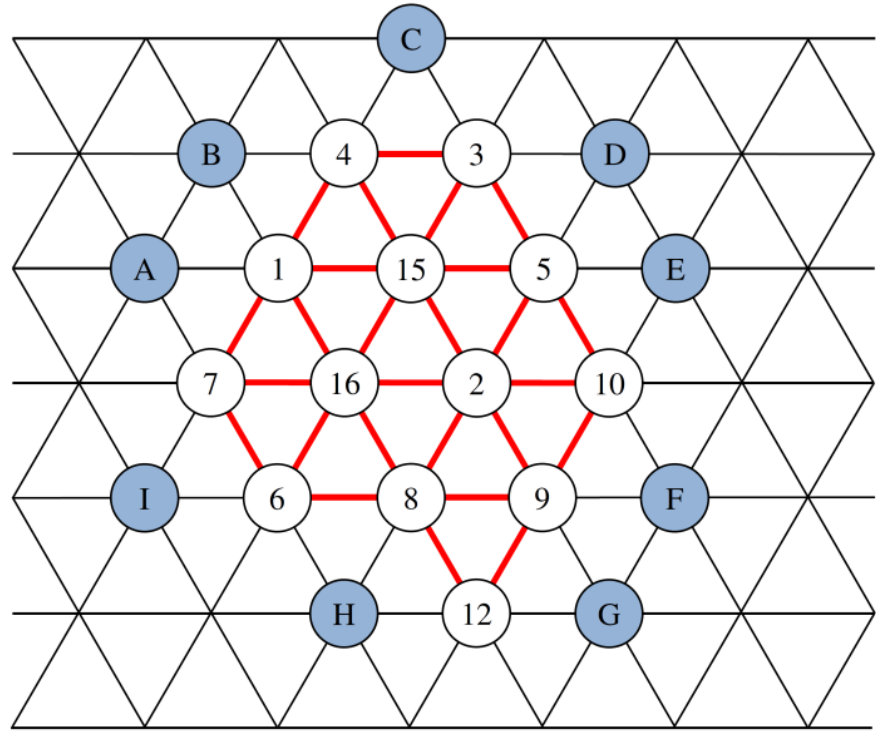

Figure 13. Placement of workstation no. 12 on the equilateral triangles network and possible placement of workstation no. 13.

Once the workstation no. 12 has been placed in the vicinity of workstations no. 8 and 9 , the goal function equals: $\mathbf{Q}=\mathbf{7 8 0 1}+\mathbf{1 2 1 0}=\mathbf{9 0 1 1}$.

Table 14.

Scope of flows of workstation no. 13, as compared with other workstations

\begin{tabular}{|c|c|c|c|c|c|c|c|c|c|}
\hline & \multicolumn{9}{|c|}{ Amount of work } \\
\hline Workstation & A & B & C & D & E & F & G & H & I \\
\hline Node & & & & & & & & & \\
1 & 0 & 0 & 0 & 0 & 0 & 0 & 0 & 0 & 0 \\
15 & 142 & 142 & 142 & 142 & 142 & 213 & 213 & 213 & 213 \\
4 & 0 & 0 & 0 & 0 & 0 & 0 & 0 & 0 & 0 \\
16 & 294 & 294 & 441 & 441 & 441 & 441 & 441 & 294 & 294 \\
2 & 0 & 0 & 0 & 0 & 0 & 0 & 0 & 0 & 0 \\
3 & 0 & 0 & 0 & 0 & 0 & 0 & 0 & 0 & 0 \\
5 & 0 & 0 & 0 & 0 & 0 & 0 & 0 & 0 & 0 \\
7 & 0 & 0 & 0 & 0 & 0 & 0 & 0 & 0 & 0 \\
6 & 0 & 0 & 0 & 0 & 0 & 0 & 0 & 0 & 0 \\
8 & 0 & 0 & 0 & 0 & 0 & 0 & 0 & 0 & 0 \\
9 & 536 & 536 & 536 & 402 & 268 & 134 & 134 & 268 & 402 \\
10 & 924 & 924 & 693 & 462 & 231 & 231 & 462 & 693 & 924 \\
12 & 376 & 376 & 470 & 376 & 282 & 188 & 94 & 94 & 282 \\
\hline Total & 2272 & 2272 & 2282 & 1823 & 1364 & $\mathbf{1 2 0 7}$ & 1344 & 1562 & 2115 \\
\hline
\end{tabular}

In line with Table 14, the next workstation, that is no. 13, will be placed in point $\mathrm{F}$. 


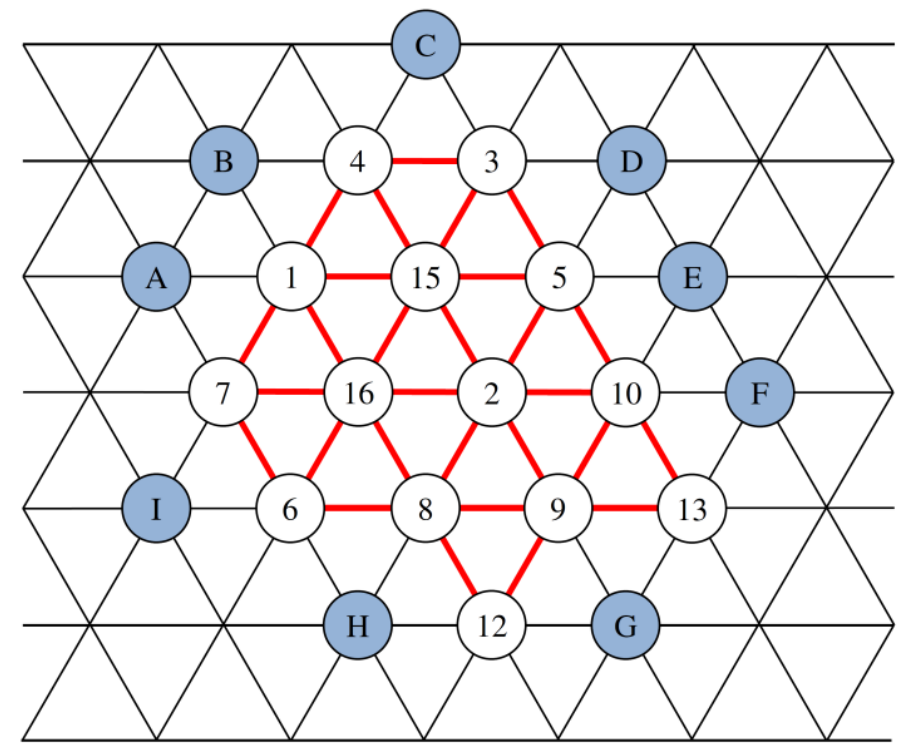

Figure 14. Placement of workstation no. 13 on the equilateral triangles network and possible placement of workstation no. 14.

Once the workstation no. 13 has been placed in the vicinity of workstations no. 9 and 10 , the goal function equals: $\mathbf{Q}=\mathbf{9 0 1 1}+\mathbf{1 2 0 7}=\mathbf{1 0 2 1 8}$.

Table 15.

Scope of flows of workstation no. 14, as compared with other workstations

\begin{tabular}{|c|c|c|c|c|c|c|c|c|c|}
\hline & \multicolumn{10}{|c|}{ Amount of work } \\
\hline Workstation & A & B & C & D & E & F & G & H & I \\
\hline Node & & & & & & & & & \\
1 & 0 & 0 & 0 & 0 & 0 & 0 & 0 & 0 & 0 \\
15 & 180 & 180 & 180 & 180 & 180 & 270 & 270 & 270 & 270 \\
4 & 0 & 0 & 0 & 0 & 0 & 0 & 0 & 0 & 0 \\
16 & 186 & 186 & 279 & 279 & 279 & 279 & 279 & 186 & 186 \\
2 & 0 & 0 & 0 & 0 & 0 & 0 & 0 & 0 & 0 \\
3 & 0 & 0 & 0 & 0 & 0 & 0 & 0 & 0 & 0 \\
5 & 0 & 0 & 0 & 0 & 0 & 0 & 0 & 0 & 0 \\
7 & 0 & 0 & 0 & 0 & 0 & 0 & 0 & 0 & 0 \\
6 & 0 & 0 & 0 & 0 & 0 & 0 & 0 & 0 & 0 \\
8 & 0 & 0 & 0 & 0 & 0 & 0 & 0 & 0 & 0 \\
9 & 784 & 784 & 784 & 588 & 392 & 392 & 196 & 392 & 588 \\
10 & 484 & 484 & 363 & 242 & 121 & 121 & 242 & 363 & 484 \\
12 & 260 & 260 & 325 & 260 & 195 & 195 & 65 & 65 & 195 \\
13 & 370 & 370 & 296 & 222 & 148 & 74 & 74 & 222 & 296 \\
\hline Total & 2264 & 2264 & 2227 & 1771 & 1315 & 1331 & $\mathbf{1 1 2 6}$ & 1498 & 2019 \\
\hline
\end{tabular}

In line with Table 15, the next workstation, that is no. 14, will be placed in point G. 


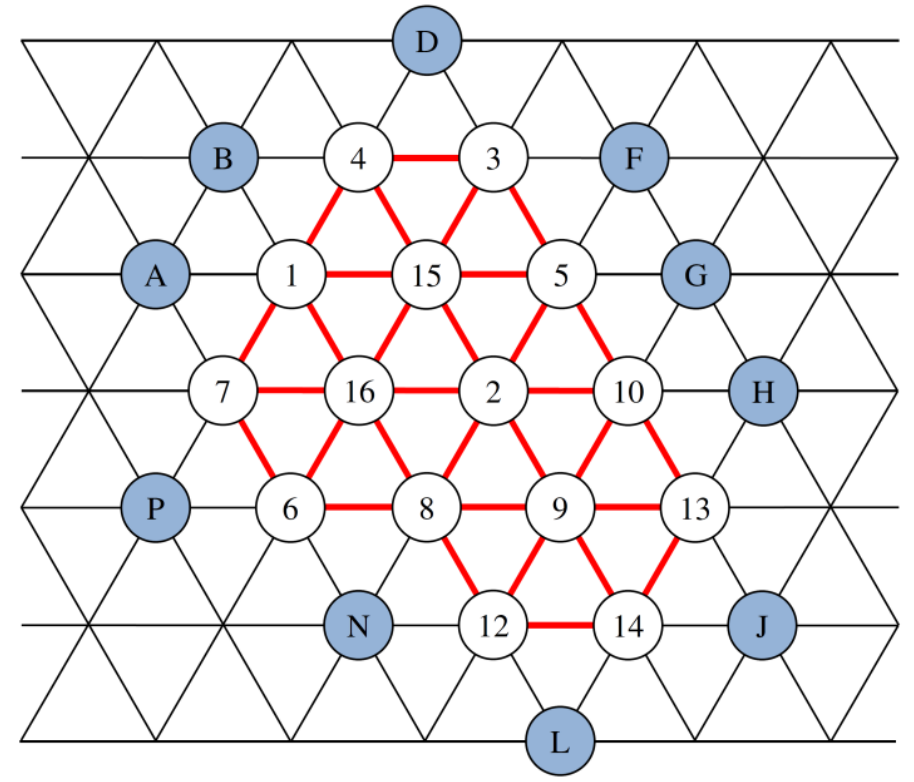

Figure 15. Placement of workstation no. 14 on the equilateral triangles network and possible placement of workstation no. 11.

Once the workstation no. 14 has been placed in the vicinity of workstations no. 9, 12 and 13 , the goal function equals: $\mathbf{Q}=\mathbf{1 0 2 1 8}+\mathbf{1 1 2 6}=\mathbf{1 1 3 4 4}$.

Table 16.

Scope of flows of workstation no. 11, as compared with other workstations

\begin{tabular}{|c|c|c|c|c|c|c|c|c|c|c|}
\hline & \multicolumn{10}{|c|}{ Amount of work } \\
\hline Workstation & A & B & D & F & G & H & J & L & N & P \\
\hline Node & & & & & & & & & & \\
1 & 0 & 0 & 0 & 0 & 0 & 0 & 0 & 0 & 0 & 0 \\
15 & 220 & 220 & 220 & 220 & 220 & 330 & 440 & 440 & 330 & 330 \\
4 & 0 & 0 & 0 & 0 & 0 & 0 & 0 & 0 & 0 & 0 \\
16 & 238 & 238 & 357 & 357 & 357 & 357 & 476 & 357 & 238 & 238 \\
2 & 0 & 0 & 0 & 0 & 0 & 0 & 0 & 0 & 0 & 0 \\
3 & 0 & 0 & 0 & 0 & 0 & 0 & 0 & 0 & 0 & 0 \\
5 & 0 & 0 & 0 & 0 & 0 & 0 & 0 & 0 & 0 & 0 \\
7 & 0 & 0 & 0 & 0 & 0 & 0 & 0 & 0 & 0 & 0 \\
6 & 0 & 0 & 0 & 0 & 0 & 0 & 0 & 0 & 0 & 0 \\
8 & 0 & 0 & 0 & 0 & 0 & 0 & 0 & 0 & 0 & 0 \\
9 & 432 & 432 & 432 & 324 & 216 & 216 & 216 & 216 & 216 & 324 \\
10 & 628 & 628 & 471 & 314 & 157 & 157 & 314 & 471 & 471 & 628 \\
12 & 284 & 284 & 355 & 284 & 213 & 213 & 142 & 71 & 71 & 213 \\
13 & 360 & 360 & 288 & 216 & 144 & 72 & 72 & 144 & 216 & 288 \\
14 & 655 & 655 & 655 & 524 & 393 & 262 & 131 & 131 & 262 & 524 \\
\hline Total & 2817 & 2817 & 2778 & 2239 & 1700 & $\mathbf{1 6 0 7}$ & 1791 & 1830 & 1804 & 2545 \\
\hline
\end{tabular}

In line with Table 16, the next workstation, that is no. 11, will be placed in point $\mathrm{H}$. 


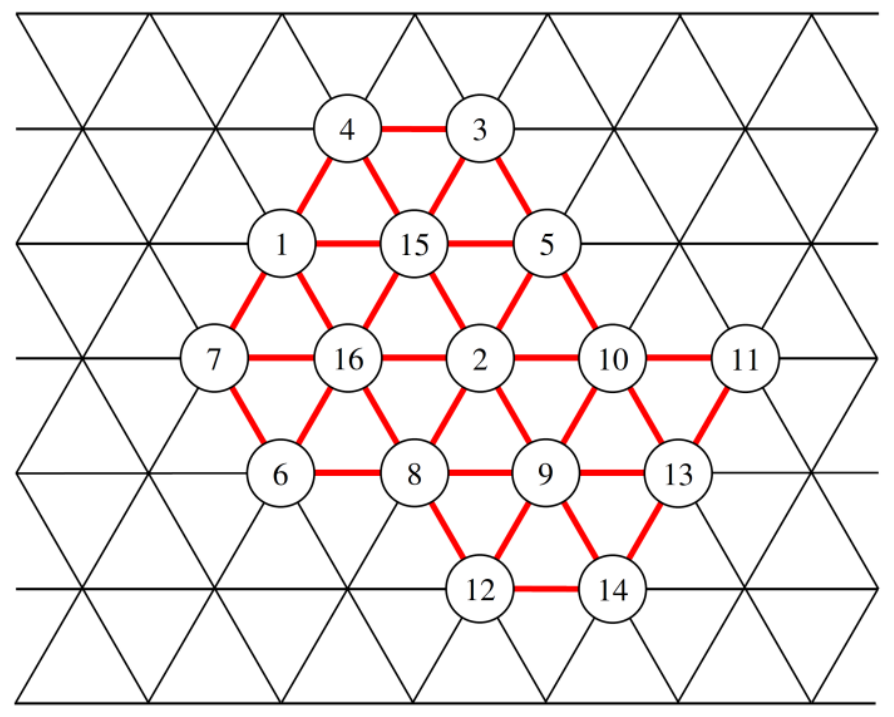

Figure 16. The final arrangement of the workstations in the commercial industry enterprise with the use of Bloch-Schmigalla triangular method.

Once all workstations were placed on the equilateral triangles network in line with BlochSchmigalla triangular method, the goal function equals: $Q=11344+1607=12951$.

The goal function value, once all workstations were placed in line with Bloch-Schmigalla triangular method, decreased by 2,644.7 units, as compared with the original placement of workstations.

\section{Conclusions}

On the basis of the analysis carried out, with the use of Bloch-Schmigalla triangular method, the following results can be presented:

- The use of Bloch-Schmigalla triangular method allowed for quick placement of workstations.

- New placement of workstations decreased the value of goal function by 2,644.7 units. As a result, the workstations will not be as loaded and specific tasks will be performed faster. The time saved can be used to complete other tasks.

- Thanks to Bloch-Schmigalla triangular method, the distances between the workstations are equal. Before, the distances between several of the workstations were greater than in the case of other ones.

- Bloch-Schmigalla triangular method can present several possible solutions. In this case, workstations 7 and 9 have more than one possible placement. As a result, the final placement of workstations can differ slightly from the one presented, but the value of goal function will still be the same.

- The new arrangement allows for easy and quick placement of a potential new workstation in the vicinity of the other ones. 


\section{Acknowledgements}

This paper was financed from the resources of the Silesian University of Technology, project no. BK-235/ROZ-1/2020 (13/010/BK_20/0042).

\section{References}

1. Bieniok, H. et al. (2004). Metody sprawnego zarzadzania. Planowanie, organizowanie, motywowanie, kontrola. Warszawa: Ploacet, p. 60.

2. Korzeń, Z. (1999). Logistyczne systemy transportu bliskiego $i$ magazynowania, Projektowanie, Modelowanie, Zarządzanie. T. II. Poznań: Instytut Logistyki i Magazynowania, p. 47.

3. Lis, S., and Santarek, K. (1980). Projektowanie Rozmieszczenia Stanowisk Roboczych. Warszawa: PWN, pp. 130-131, 138-139.

4. Martyniak, Z. (1999). Metody organizacji i zarządzania. Kraków: Wydawnictwo Akademii Ekonomicznej, pp. 122-123.

5. Matusek, M. (2012). Doskonalenie przepływu materiałów w U-kształtnej linii montażu. Zeszyty Naukowe Politechniki Ślaskiej, seria: Organizacja i Zarzadzanie, 60, p. 193.

6. Mikołajczyk, Z. (1995). Techniki organizatorskie w rozwiązywaniu problemów zarzadzania. Warszawa: PWN, pp. 289-290.

7. Muhlemann, A.P., Oakland, J.S., and Lockyer, K.G. (1995). Zarzadzanie. Produkcja i Ustugi. Warszawa: PWN, p. 180.

8. Pająk, E., Klimkiewicz, M., and Kosieradzka, A. (2014). Zarządzanie produkcja i ustugami. Warszawa: PWE, p. 140.

9. Pasternak, K. (2005). Zarys zarzadzania produkcją. Warszawa: PWE, pp. 147-148, 156.

10. Stabryła, A., and Trzcieniecki, J. (Eds.) (1986). Organizacja i zarzadzanie. Zarys problematyki. Kraków: Akademia Ekonomiczna, pp. 376-377, 384-385, 390, 392.

11. Strojek-Filus, M., Krynke, M., and Zasadzień, M. (2018). Wybrane aspekty funkcjonowania przedsiębiorstwa - koszty, konkurencyjność, jakość. Gliwice: Wydawnictwo P.A. NOVA.

12. Wolniak, R., Skotnicka-Zasadzień, B., and Gembalska-Kwiecień, A. (2018). Identification of bottlenecks and analysis of the state before applying lean management. 12th International Conference Quality Production Improvement - QPI 2018, Zaborze near Myszków, Poland, June 18-20, 2018 [online]. R. Ulewicz, and B. Hadzima (eds.). Les Ulis: EDP Sciences, (pdf file), art. 01001, pp. 1-6. 
13. Zasadzień, M., Wolniak, R., and Skotnicka-Zasadzień, B. (2017). Doskonalenie procesu produkcji worków foliowych przy wykorzystaniu wybranych metod i narzędzi inżynierii jakości. In: B. Skotnicka-Zasadzień (Ed.), Systemy. Wspomagania. Inżynierii. Produkcji. Sposoby i środki doskonalenia produktów i ustug na wybranych przykładach, 6(8), pp. 37-48.

14. Zielecki, W., and Sęp, J. (2014). Wspomaganie projektowania linii produkcyjnych U-ksztaltnych metoda programowania sieciowego. Opole: Oficyna Wydawnicza Polskiego Towarzystwa Zarządzania Produkcją, pp. 682-683.

15. Zimniewicz, K. (2009). Współczesne Koncepcje i Metody Zarządzania. Warszawa: PWE, pp. 65-66. 